УДК61 (007):613.96:613.71

\title{
МОТИВАЦІЯ ДО ЗАНЯТЬ ФІЗИЧНОЮ КУЛЬТУРОЮ СТУДЕНТІВ ВИЩИХ МЕДИЧНИХ НАВЧАЛЬНИХ ЗАКЛАДІВ
}

\author{
В. Й. Шатило, І. Ю. Андрісвський, О. В. Дронова \\ Житомирський інститут медсестринства, \\ Вінницький базовий медичний коледж імені акад. Д. К. Заболотного, \\ Конотопське медичне училище Сумської області
}

\section{MOTIVATION TO CLASSES IN PHYSICAL TRAINING OF STUDENTS OF HIGHER EDUCATIONAL MEDICAL ESTABLISHMENTS}

\author{
V. Y. Shatylo, I. Yu. Andriyevskyi, O. V. Dronova \\ Zhytomyr Institute of Nursing, \\ Vinnytsia Base Medical College by D. K. Zabolotnyi, \\ Konotop Medical College of Sumy region
}

\begin{abstract}
У статті розглянуті перспективні підходи до підвищення мотивації студентів до занять фізичною культурою $з$ метою забезпечення ведення здорового способу життя та підвищення рівня успішності.

The article adduces the perspective approaches that increase the motivation of students to classes in Physical Training with the purpose to provide the healthy way of life and increase the level of progress in studies.
\end{abstract}

Вступ. Фізична культура особистості вважається основою соціально-культурного буття індивіда, невід'ємним складником його загальнолюдської й професійної компетентності. Як інтегрований результат виховання й професійноїпідготовки фізична культура особистості визначається ставленням людини до свого психосоматичного здоров'я, рівнем розвитку фізичних можливостей, а також активністю життевої позиції.

Стан здоров'я сучасної студентської молоді є однією з найактуальніших проблем сьогодення. Законодавчі й нормативні документи про вищу освіту спрямовують увагу вчених і педагогів - практиків на фізичне та моральне здоров'я нації [8].

Процес формування інтересу до занять фізичною культурою і спортом - це не одномоментний, а багатоступеневий процес: від перших елементарних гігієнічних знань і навиків (у дитячому віці) до глибоких психофізіологічних знань теорії і методики фізичного виховання і інтенсивних занять спортом [2].

Із року в рік збільшується кількість студентів, що мають звільнення від занять фізичною культурою. На сьогодні лише 79,4 \% студентів медичних коледжів області регулярно відвідують заняття з фізичної культури, а цілеспрямовано займаються фізичною культурою і ведуть здоровий спосіб життя лише 17,3\%.
Сьогодні соціальне середовище і реальна практика свідчать про погіршення здоров'я молоді, збільшення ваги, загострення серцево-судинних захворювань та інших хронічних іінфекційних захворювань [5].

Сьогоднішній рівень урбанізації, науково-технічного прогресу, побутового комфорту є причиною хронічного "рухового голоду".

Насамперед це стосується студентської молоді, оскільки студенти - це основний трудовий резерв нашої країни, це майбутні батьки, i ïх здоров'я та благополуччя $є$ запорукою здоров'я і благополуччя всієї нації. У зв'язку з цим величезного значення і актуальності набуває вивчення інтересів і потреб сучасної молоді у сфері фізичної культури. Велика роль тут відводиться медичній сестрі в розробці методів мотиваційного стимулювання [1].

Студентство, особливо на початковому етапі навчання, $\epsilon$ найуразливішою частиною молоді, оскільки стикається 3 низкою труднощів, пов'язаних із збільшенням навчального навантаження, невисокою руховою активністю, відносною свободою студентського життя, проблемами в соціальному і міжособовому спілкуванні [3].

За останні роки, як відзначають деякі дослідники, доних додалася інтенсифікація навчальних процесів,

() В. Й. Шатило, І. Ю. Андрієвський, О. В. Дронова 
необхідність поєднання навчання 3 роботою, погіршення харчування, розповсюдження тютюнокуріння, вживання алкоголю [6].

Сьогодні лише лунають заклики бути здоровим, а соціальне середовище і реальна практика свідчать про погіршення здоров'я молоді, збільшення ваги, загострення серцево-судинних захворювань та інших хронічних і інфекційних захворювань [4].

Мета дослідження: науково обгрунтувати педагогічні аспекти ролі медичного працівника у визначенні позитивної мотивації занять фізичною культурою.

Для досягнення мети використано такі методи: медико-соціологічне дослідження (анкетування) та методи системного аналізу і логічного узагальнення, методи математичної статистики.

Основна частина. Створення педагогічних умов, спрямованих на активізацію досліджуваного процесу, відбувалося в ході дослідно-експериментальної роботи зі студентами I-IV курсів Житомирського інституту медсестринства і Конотопського медичного коледжу Сумської області. Анкетування, проведене серед студентів, показало, що в середньому молодь усвідомлює саме значення фізичної культури в життєдіяльності людини.

Модифікована анкета містила 23 питання відкритого і альтернативного типів, передбачалася можливість як одного, так і декількох варіантів відповіді.

За даними соціологічного дослідження, 97,8 \% студентів регулярно відвідують заняття у ВНЗ, проте цілеспрямовано займаються фізичною культурою тільки 23,2 \%. При цьому $92 \%$ студентів згодні 3 тим, що фізична активність покращує їх здоров'я.

На даний час значно скоротилася кількість практично здорових студентів. Нами був проведений також аналіз стану здоров'я студентів різних курсів: $49 \%$ студентів першого курсу, 52 \% другого курсу, $50 \%$ третього курсу, $45 \%$ - четвертого.

Більшість студентів першого курсу суб'єктивно оцінюють стан свого здоров'я як хороше - $69 \%$, останні вважають своє здоров'я в межах норми.

Серед студентів другого курсу картина зворотна 37 \% вважають своє здоров'я хорошим, всі інші - в межах норми. $12 \%$ третьокурсників оцінили своє здоров' я як погане, 60 \% - в межах норми і $28 \%$ як хороше, близько 33 \% студентів IV курсу відмітили рівень свого здоров' я як хороше.

Регулярно займаються фізичною культурою у вільний час 37 \% першокурсників, 32 \% другокурсників, $29 \%$ студентів третього курсу, $26 \%$ четвертого. Самостійно займаються $33 \%$ студентів пер- шого курсу, 44 \% - другого, 47 \% - третього і $39 \%$ четвертого. Окрім того, 30 \% першокурсників не бачать для себе необхідності в заняттях, а також $24 \%$ студентів другого і третього курсів та $35 \%$ четвертого курсу. Останні не займаються через суб' єктивні причини, усвідомлюючи, проте, позитивне значення занять. Такі результати підтверджують незадоволеність студентів заняттями у ВНЗ: більшість вважає за краще займатися самостійно або додатково.

Результати з цього питання узгоджуються з питаннями про задоволеність заняттями у ВНЗ і причинами відмови від додаткових занять. Дівчата вважають за краще заняття нетрадиційними видами фізичної культури, які не включені до програми ВН3 і вимагають значних фінансових вкладень, які студентки не можуть собі дозволити. Молоді люди віддають перевагу спортивним іграм, і хоча вони включені до програми, але безкоштовні секції відсутні.

Домінуючою мотивацією в заняттях фізичною культурою у дівчат є бажання поліпшити фігуру, поставу, схуднути (47 \%); з другорядних мотивацій провідне місце займає бажання укріпити здоров' я (47 \%).

У молодих людей домінуючою також є мотивація поліпшення фігури, нарощування м'язової маси (32 \%). 3 другорядних домінуючою мотивацією виявилося бажання зміцнити здоров' я (41%).

Володіння фізичною культурою є неодмінною умовою здорового способу життя. 3 цією метою у навчальному закладі необхідно з перших днів навчального року ввести курс лекцій з наукової організації праці, депознайомити студентів із психофізіологічними і педагогічними основами здорового способу життя, дати їм практичні рекомендації щодо його раціональної організації [7].

Підвищення ціннісно-мотиваційного відношення студентів до фізичної культури. Відомо, що середні величини витрат часу на фізичну культуру в структурі вільного часу студентів за тиждень складають 6-10\%. Таку малу кількість часу, що приділяється на фізичну культуру, можна пояснити низькою потребою в цій сфері діяльності.

Систематична рухова діяльність у всіх випадках викликає покращання функціональних можливостей нервового апарату, причому у студентів, що активно займаються фізичною культурою, позитивні результати вище, ніж у тих, що не займаються. Оптимальні фізичні навантаження в режимі навчального дня, безпосередньо підвищуючи функціональну діяльність системи м'язів, позитивно впливають на психологічну сферу студентів, а саме на розумові процеси. Разом $з$ тим, порушення навчально-тренувального ре- 
жиму супроводжуються розладом не тільки моторики, але і коркових нервових процесів. Фізичні навантаження неадекватні функціональним можливостям, знижують працездатність головного мозку, що необхідно враховувати при організації навчальних занять студентів [10].

У студентів молодших курсів однією з причин низької успішності є недостатньо розвинена увага. Заняття фізичною культурою допомагають розвинути в них довільну увагу. Після фізичного тренування у студентів-спортсменів присутній найвищий відсоток успішного вирішення задач, пов' язаних з утриманням в оперативній пам'яті результатів попередніх дій. Включення фізкультурних пауз як у першій, так і в другій половині навчального дня також сприяє активізації розумової працездатності.

Різке скорочення рухової активності в період екзаменаційної сесії викликає несприятливі зрушення функціонального стану до їі кінця. У студентів, які продовжували заняття фізичними вправами в період екзаменаційної сесії, середній бал склав 4,16 $\pm 0,06$, а кількість

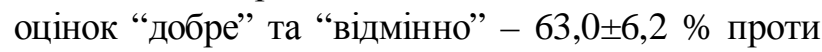
$3,96 \pm 0,05$ балів та 49,0 $3,1 \%$ у тих, що не займалися.

Серед відмінників навчання більше тих, хто використовує засоби загартовування та ранкової гімнастики. Серед студентів, що регулярно займаються спортом, більший відсоток встигаючих на “добре” та “відмінно".

В ході нашого дослідження ми також вивчали фактори стимулювання самостійних занять фізичною культурою студентів першого курсу. Метою самостійних занять фізичною культурою студентів повинна бути ліквідація функціональних відхилень і недоліків фізичного розвитку, підтримка високого рівня професійної працездатності, зміцнення здоров'я, загартовування. Безумовно, керування самостійними заняттями повинно здійснюватися медичною сестрою та викладачем фізичного виховання.

Вправи протягом навчального дня (фізкультурні паузи) виконуються між навчальними чи самостійними заняттями. Зміст і методика виконання цих вправ подібні до ранкової гімнастики. Це можуть бути вправи $з$ удосконалення елементів техніки спортивних $\mathrm{i}$

\section{Лiтература}

1. Агапова О. Проектно-содержательная модель обучения / О. Агапова, А. Кривошеев, А. Ушаков // Alma mater. 2004. - № 12. - С. 22-30.

2. Андреєва В. Г. Соціальна психологія / В. Г. Андреєва. M., 2005. -432 c. трудових рухів, з розвитку відсутніх фізичних якостей. Це також може бути комплекс вправ для осіб певної категорії професій (виробнича гімнастика). 3 одного боку, це може бути комплекс для осіб розумової праці, до категорії яких відносяться студенти, з іншого - комплекс вправ для працівників тієї професії, до якої готується студент [9].

Висновки. Між успішністю студентів та їх фізичною підготовленістю існує певний взаємозв'язок. Якість навчання студентів залежить не тільки від рівня їх загальноосвітньоїпідготовки, професорськовикладацького складу, забезпечення навчальних кабінетів та лабораторій, але і від стану здоров'я та фізичної підготовленості. Регулярні заняття фізичною культурою допомагають своєчасно переключити нервову систему студента з одного виду діяльності на інший.

У студентів молодших курсів однією з причин низької успішності є недостатньо розвинена увага. Заняття фізичною культурою допомагають розвинути в них довільну увагу. Після фізичного тренування у студентів-спортсменів присутній найвищий відсоток успішного вирішення задач, пов'язаних з утриманням в оперативній пам'яті результатів попередніх дій. Включення фізкультурних пауз як у першій, так і в другій половині навчального дня також сприяє активізації розумової працездатності. Психофізичні функції студентів, що відпочивають між заняттями пасивно, у більшості випадків не змінюються.

Головні напрямки роботи медпрацівника закладу, у нашому випадку медичної сестри, полягають в наступному:

- медична сестра як спеціаліст з фаху повинна досконало вивчити організацію занять $з$ фізичного виховання у ВНЗ;

- як кваліфікований фахівець медична сестра може вказувати на недоліки в процесі навчання та давати рекомендації щодо їх усунення з медичної точки зору; - здійснювати постійний медичний контроль над динамікою стану здоров' я та самопочуття студентів;

- навчати студентів самостійно організовувати заняття фізичними вправами і здійснювати самоконтроль свого фізичного і психічного стану.

3. Андрущенко В. Університетська освіта України: європейський вибір / Володимир Андрущенко // Освіта. - 2003. -29 серпня.

4. Анпілогов I. Е. Дослідження уявлень про значення життєвих цінностей в спорті студентів : магіст. дис. / 
I. Е. Анпілогов. - Смоленськ, 2007. - 82 с.

5. Анурін В. Ф. Ціннісні орієнтації та їх вплив на формування потреб / В. Ф. Анурін // Соціологія вищої школи підготовки студентів : зб. наук. пр. - Горький, 2004. - С. 116129.

6. Артемов С. В. Запросы и потребности населения как базовый фактор планирования развития физической культуры и спорта городского района : автореф. дис. канд. пед. наук / С. В. Артемов. - М., 2003. - 19 с.

7. Асеев В. Г. Мотивация поведения и формирование личности / В. Г. Асеев. - М. : Мысль, 2003. - 158 с.

8. Байта М. К. Соціально-педагогічні умови моральногови- ховання студентів упізнавальній діяльності : автореф. дис. канд. пед. наук/Микола Костянтинович Байта. -К., 2004. -20 с.

9. Бальсевич В. К. Фізична культура: молодь і сучасність / В. К. Бальсевич, Л. И. Лубишева // Теорія і практика фізичної культури. -К., 2005. - № 5. - С. 5-12.

10. Барановская Д. И. Роль физкультурных занятий в формировании мотивации к занятиям физической культурой студенческой молодежи / Д. И. Барановская, В. И. Врублевская // Актуальные проблемы оздоровительной физической культуры и спорта для всех на современном этапе : материалы VIII Междунар. науч. сессии по итогам НИР за 2004 г. - Минск : БГУФК, 2005. - С. 13-16. 